\title{
Perceived Teacher Self-Efficacy of Teacher Candidates Enrolled in the Pedagogical Formation Certificate Program
}

\author{
Sabri Güngör ${ }^{1} \&$ Yalçın Özdemir ${ }^{2}$ \\ ${ }^{1}$ Faculty of Education, Kafkas University, Kars, Turkey \\ ${ }^{2}$ Faculty of Education, Niğde Ömer Halisdemir University, Niğde, Turkey \\ Correspondence: Sabri Güngör, Faculty of Education, Kafkas University, Merkez Yerleşke, 36100, Merkez, Kars, \\ Turkey
}

Received: November 14, 2017

Accepted: November 30, $2017 \quad$ Online Published: December 7, 2017

doi:10.5430/ijhe.v6n6p112

URL: https://doi.org/10.5430/ijhe.v6n6p112

\begin{abstract}
This study aims to determine the variables affecting teacher candidates' perceived self-efficacy levels. The study was conducted with 560 students who attended the pedagogical formation programs, a type of teacher training program, run by two different universities in Turkey during the academic year of 2016-2017. The data was obtained by Teachers' Sense of Efficacy Scale, developed by Tschannen-Moran and Hoy (2001) and adopted to Turkish by Çapa, Çakıroğlu and Sarıkaya (2005). SPSS package program was used for data analysis, and percentage, arithmetic mean, standard deviation, independent groups t-test, one-way analysis of variance (ANOVA) and LSD test were used for the analysis of data. According to the study findings, candidates' views on self-efficacy differ according to their ages, sexes, universities, settlements they have lived the longest, faculties and mother's education level while their self-efficacy views did not differ according to their own and father's education level. As the teacher candidates' ages increased, their self-efficacy also increased. Males compared to females, Kafkas University's students compared to Niğde Ömer Halisdemir University's students, the students who have lived in metropolises the longest compared to others, students from faculties who accept students with ability exams compared to other faculties considered themselves more efficacious about teaching.
\end{abstract}

Keywords: Teacher self-efficacy, Pedagogical formation education, University students, Prospective teachers

\section{Introduction}

As institutionalized structures, education systems want to shape human subjects through formal processes while people in these institutions interpret formal processes and want to shape them in their own way. Educational institutions can therefore be regarded as areas of mutual dialectic interaction between the structure and human subject. Teachers' behaviors related to teaching can also be interpreted through this dialectic relationship. Teachers with high quality of knowledge, skills and attitudes are essential for education systems. On the other hand, the question of how much teachers will use this potential, i.e., the question of how they will behave in their professional lives can be interpreted within this dialectic relationship. Teachers' perceived self-efficacy is important in enriching our understanding of the dialectic relationship between education systems and teachers and of teachers' realization levels of their professional potential.

\subsection{Concept of Self-Efficacy}

Although it is one of the central concepts in social psychology, the concept of self-efficacy can also be associated with many theoretical discussions in the context of human behavior like tensions between determinism and indeterminism, voluntarism and intentionality and structure/environment-subject (Gecas, 1989). In this sense, the concept has an important place in discussions about how free human action is or whether people are a simple product of the social environment. The meaning that Bandura puts into concept of self-efficacy, which he places at the center of social cognitive theory, stands out in this context in explaining the mutual dependency between personal agency and social structure. In a sense, social cognitive theory and the concept of perceived self-efficacy should be regarded as a rejection of any dualism between social structures and personal subject (Ballesteros, Nicolás, Caprara, Barbaranelli \& Bandura, 2002). In this respect, self-efficacy should be interpreted as a construct derived from social cognitive theory, which assumes human behavior, cognition and environment shape each other dynamically through mutual triple causal effect (Gist \& Mitchell, 1992). 
In social cognitive model, intrinsic personal factors in cognitive form, affective and biological events, behavior patterns and all environmental phenomena are considered as interactive variables interacting with each other (Bandura, 1999). At this point, Bandura (1999) places the concept of perceived self-efficacy at the center of social cognitive theory and the process of people's meaning making as subjects interpreting and shaping their environment as well as being shaped by the environment:

Among the mechanisms through which human agency is exercised, none is more central or pervasive than beliefs of personal efficacy. This belief system is the foundation of human agency. Unless people believe that they can produce desired effects by their actions they have little incentive to act or to persevere in the face of difficulties. Whatever other factors serve as motivators, they are rooted in the core belief that one has the power to produce changes by one's actions (Bandura, 1999, 28).

Therefore, perceived self-efficacy is the judgment of people about themselves and about their own potential. In other words, "Perceived self-efficacy is concerned with people's judgments of their capabilities to execute given levels of performance" (Bandura, 1984, 232). This distinction between people's performance capacities and judgments regarding this capacity puts environmental factors making up this capacity, i.e. the environment, and the personal perception, i.e. the subject, inside understanding human behavior.

Bandura (Bandura \& Adams, 1977) constructed perceived self-efficacy through four main sources of information. The most effective efficacy information comes from performance accomplishments since it depends on personal mastery experiences. The other sources of information are vicarious experiences of observing other people succeed through their efforts, verbal persuasion that a person has capacity to cope successfully, and states of physiological arousal from which people can understand their own level of anxiety (Bandura \& Adams, 1977).

On the other hand, according to Bandura (2002), cultural factors cause the concept self-efficacy to be defined differently in different cultural environments. Bandura explains this view with the example of children in authoritarian education systems having less self-efficacy about taking responsibility of their own learning even though children in different countries have equal self-efficacy. Ballesteros et al. (2002) points out that different types of perceived efficacy can differ according to age and gender. For example, although males and females do not differ in their perceived efficacy to manage their own lives, males have stronger perceived efficacy to change their lives for the better through social change.

\subsection{Perceived Teacher Self-Efficacy}

Bandura (1984) points that there is a significant difference between people having important cognitive, social and motor subskills and using them effectively for different purposes under different situations. When teacher self-efficacy is examined, it can be said that teachers exhibiting homogeneity about the necessary teaching knowledge, skills and attitudes may not always realize this capacity they have at a homogenous level because individuals with the same skills may perform these skills differently according to their use, combination and ranking (Gist \& Mitchell, 1992). Therefore, perceived self-efficacy is one of the most important variables affecting teacher competencies, decision-making processes in teachers' professional lives and teachers' behaviors. Before discussing the effect of perceived teacher self-efficacy on teacher behavior, it will be meaningful to discuss some of the effects of self-efficacy on individuals' behaviors.

According to Bandura, perceived self-efficacy may affect individuals in terms of self-enhancing or self-debilitating (Benight \& Bandura, 2004). Similarly, Bandura and Adams (1977) argues that perceived self-efficacy affect people's activity choices, behavior systems, how much effort they make and how insistent they are when confronting obstacles or dissuasive experiences. Thus, strong perceived self-efficacy means making more effort to cope. A contrary situation will lead to avoidance, and these people will continue their self-debilitating and defensive expectations (Bandura \& Adams, 1977). Individuals with high perceived self-efficacy set challenges for themselves, increase their effort when their performances do not meet their purposes, continue trying despite repeated failures, exhibit less anxious behavior by stressing less (Bandura, 1984). On the other hand, low perceived self-efficacy can lead to avoiding difficult tasks, decreasing effort, giving up when faced with difficulties, focusing on personal weaknesses thus loosing attention while on task, and higher anxiety and stress, thus causing negative performance by hindering the performance of existing potential (Bandura, 1984). Therefore, perceived self-efficacy influences personal motivation, career choice, people's causal explanation styles regarding their performances, decision-making processes regarding what actions to take in the future and how to confront the results of actions, and thus can shape the potential to become a subject (Bandura, 1999). 
One of the most basic requirements of any educational system claiming to be qualified is to have teachers with high levels of efficacy and quality. Teacher efficacies are defined as the knowledge, skills and attitudes needed to fulfill the teaching profession effectively and efficiently (MEB, 2008, VIII), and are considered as a national priority (TED, 2009). Perceived teacher self-efficacy has a different meaning than teacher competency. Teacher self-efficacy refers to teachers' own thoughts and judgments about teaching (Schunk, 2009) or teachers' judgment about whether they can produce desired outcomes like loyalty and learning with the skills they have (Tschannen-Moran \& Hoy, 2001).

Studies on perceived teacher self-efficacy show similarities with the explanations given above regarding self-efficacy. Many studies put forth that perceived teacher self-efficacy has a significant effect on attitudes and behaviors towards teaching and teachers' competencies. For example, perceived teacher efficacy and thus their readiness for teaching is an important indication on how well they will confront the problems in their profession (Brown, Lee \& Collins, 2015).

Perceived teacher self-efficacy is important not only for working teachers' behaviors but also for understanding the teacher training processes and teacher candidates' behaviors. For example, Gist (1987) argued that self-efficacy can also be used in determining training needs, explaining problems regarding the training process and professional guidance and direction. It was found that there is appositive relationship between teacher candidates' self-efficacy beliefs and their positive emotions towards teaching (Brigido, Borrachero, Bermejo \& Meallado, 2013). Also, it is emphasized that there is a relationship between teacher candidates' perceived teacher self-efficacy and teacher training curricula and programs. For example, Yeung and Watkins (2000) point out that the teacher training curriculum is under a wide umbrella including personal constructs regarding educational thoughts that the teacher candidates attain through educational practices and self-discoveries. They argued that self-efficacy influence the way candidates learn teaching, their perceptions, judgments and activities like decision-making within the classroom (Yeung \& Watkins, 2000). Petchauer (2016) concluded that there is a relationship between candidates' self-efficacy and educational programs. The following are their recommendations to develop teacher candidates' self-efficacy in teacher training programs: Teacher training programs should offer sufficient information sources to the students as early as possible. These programs should be designed in such a way that mastery experiences can be gained very frequently and quickly. Programs should be run in such a way that students can contribute to their successful experiences regarding their own skill development. Programs should celebrate and praise students' successful experiences in certification exams (Petchauer, 2016). Brown et al. (2015) found that candidates' self-efficacy prior to entering the program improved after they completed their studies. In other words, teacher training programs had an effect on self-efficacy. Bümen and Özaydın (2013) also concluded that candidates' self-efficacy improved between the time they started the program and the time they finished it.

Tuchman and Isaacs (2011) put forth that formal pre-service training, positive candidate experiences and informal pre-service experiences are all related. In the study, it was found that formal and informal pre-service experiences were associated with different dimensions of teacher self-efficacy. Accordingly, while formal teacher training processes are strongly associated with competences regarding educational practices, positive informal experiences are mostly associated with self-efficacies regarding student engagement. Similarly, Menon and Sadler (2016) determined that specific courses in teacher training positively affected teacher candidates' knowledge related to the course and their self-efficacy related to the subject. In other words, training process has a significant effect on the candidates' self-efficacy.

There are study results that show that teacher candidates' perceived self-efficacy will affect their achievement when they start teaching (Caprara, Barbaranelli, Steca \& Malone, 2006; Goddard, Hoy \& Hoy, 2000). Likewise, there are many studies on showing the relationship between teachers' perceived self-efficacy and effective teacher characteristics like implementing new instructional techniques, devoting more time to teaching (Guskey, 1988; Stein \& Wang, 1988), preventing unwanted student behavior in classroom, having class management skills (Woolfolk \& Hoy, 1990) and devotion to the profession (Caprara et al., 2006). In Turkey, many studies on teachers' and teacher candidates' self-efficacy (Ünlü, Kaşkaya \& Kızılkaya, 2017; Dadandı, Kalyon ve Yazıcı, 2016; Kutluca \& Aydın, 2016; Yeşilyurt, 2013; Baykara, 2011; Demirtaş, Cömert \& Özer, 2011; Şahin-Taşkın \& Haciömeroğlu, 2010; Karadağ, Baloğlu \& Çalışkan, 2009; Özdemir, 2008; Çapri \& Çelikkaleli, 2008; Morgül, Seçken \& Yücel, 2004) examined perceived self-efficacy of teacher candidates in education faculties. However, almost all of these studies were conducted with participants from one university. In this respect, it is hoped that this study will contribute by fulfilling a need in the literature.

Because of these reasons, this study aims first to determine teacher candidates' perceived self-efficacy and later to examine whether their self-efficacy differ significantly according to their ages, sexes, education levels, settlements 
they have lived the longest, faculties, universities where they are enrolled for teacher training program, and mother's and father's education levels.

\section{Methods}

\subsection{Research Model}

Aiming to examine perceived teacher self-efficacy of teacher candidates who are attending pedagogical formation certificate programs, this study is a survey research. According to Creswell (2014), survey designs are approaches seeking to describe a situation that have existed in the past and still exists today as it is and as it occurs within its own conditions. With the model employed in this study, efforts were made to qualitatively describe teacher candidates' views on their self-efficacy as it is and without making any changes like Karasar (2012) stated.

\subsection{Study Group}

560 teacher candidates were randomly selected for the study. Studying at Kafkas University (KU) and Niğde Ömer Halisdemir University (NOHU) to become teachers, these candidates were made up of fourth-year students from faculties other the education faculty and graduates. The study was conducted in January, 2017. The participating 560 certificate program students are made up of graduates and students from the same faculties of the two universities. These faculties consist of Faculty of Arts and Science, Faculty of Economics and Administrative Sciences and School of Physical Education and Sports, respectively.

\subsection{Data Collection Tools}

Teachers' Sense of Efficacy Scale, developed by Tschannen-Moran and Hoy (2001), was used for data collection. The adaptation of the scale to Turkish and its validity and reliability works were done by Çapa, Çakıroğlu and Sarıkaya (2005). Personal information form, developed by the researchers, was used to collect participants' personal information.

\subsubsection{Teachers' Sense of Efficacy Scale}

The scale consists of 24 nine-point likert type items. There are eight items under the "Student Engagement", "Instructional Practices" and "Classroom Management" subscales. As can be understood from the subscales, the scale incudes the basic subscales that a qualified teacher must have. The highest score participants can get from the scale is $216.00(24 \times 9)$ and the lowest score is $24.00(24 \times 1)$. The highest score participants can get from each subscale is $72.00(8 \times 9)$ and the lowest is $8.00(8 \times 1)$. The validity and reliability work of the scale's adaptation was carried out with administering the scale to 628 teacher candidates. After the factor analysis done to determine the scale's construct validity, it is seen that the factor loadings of the items range between $0.49-0.74$. In the analysis done for the Turkish adaptation's reliability, alpha values were found .82 for Student Engagement subscale, .86 for Instructional Practices subscale, .84 for Classroom Management subscale and .94 for the total scale. Findings from the validity and reliability works reveal that the scale is valid and reliable (Çapa et al., 2005).

\subsubsection{Personal Information Form}

To make comparative analysis of the collected data from the scale, the researchers developed a personal information form including personal information about variables like age, sex, education level, the settlement lived the longest, faculty, mother's and father's education level.

\subsection{Procedure}

The data used in the study was obtained from students who were attending the pedagogical formation certificate program in 2016-2017. Teachers' Sense of Efficacy Scale was administered to the candidates that wanted to participate in the study. Before administering the scale, researchers briefly explained the study purpose and how the scale will be filled out. 20 minutes needed to fill out the scale were given to the candidates, and researchers made sure the participants filled the items appropriately. They, also, tried to solve possible problems by staying in the classroom during the scale's administration to solve possible problems. The data was collected within a week.

\subsection{Data Analysis}

One-way analysis of variance was performed to assess whether candidates' perceived teacher self-efficacy differed according to ages (20-21, 22-23, 24-25, 26 and over), settlements they have lived the longest (village-town, district, city, metropolis), faculties (Arts and Science, FEAS, SPEA), mother's education level (illiterate-literate, elementary school, middle school, high school and university graduate) and father's education levels (illiterate-literate, elementary school, middle school, high school and university graduate), and independent t-test to determine whether their perceived teacher self-efficacy differed according to sex (female-male), education level (graduate-student) and 
university (KU-NOHU). The data analysis was done by SPSS 20.0. Significance level used in the interpretation of analysis was determined as 0.05 .

\section{Results}

\subsection{Socio-demographic Characteristics of Participants}

Table 1 shows the socio-demographic characteristics of participants participating in the study.

Table 1. Socio-demographic characteristics of participants

\begin{tabular}{|c|c|c|c|c|c|c|c|}
\hline \multirow{2}{*}{$\begin{array}{l}\text { Socio-demographic } \\
\text { Characteristics }\end{array}$} & & \multicolumn{2}{|l|}{$\mathrm{KU}$} & \multicolumn{2}{|l|}{ NOHU } & \multicolumn{2}{|l|}{ Total } \\
\hline & & $N(247)$ & $\%$ & $N(313)$ & $\%$ & $N(560)$ & $\%$ \\
\hline \multirow{4}{*}{ Age } & $20-21$ & 33 & 13.4 & 52 & 16.6 & 85 & 15.2 \\
\hline & $22-23$ & 113 & 45.7 & 164 & 52.4 & 277 & 49.5 \\
\hline & $24-25$ & 67 & 27.1 & 50 & 16 & 117 & 20.9 \\
\hline & 26 and over & 34 & 13.8 & 47 & 15 & 81 & 14.5 \\
\hline \multirow{2}{*}{ Sex } & Female & 139 & 56.3 & 216 & 69 & 355 & 63.4 \\
\hline & Male & 108 & 43.7 & 97 & 31 & 205 & 36.6 \\
\hline \multirow{2}{*}{ Education level } & Graduate & 40 & 16.2 & 56 & 17.9 & 96 & 17.1 \\
\hline & Student & 207 & 83.8 & 257 & 82.1 & 464 & 82.9 \\
\hline \multirow{4}{*}{ Settlement } & Village-town & 54 & 21.9 & 55 & 17.6 & 109 & 19.5 \\
\hline & District & 77 & 31.2 & 90 & 28.8 & 167 & 29.8 \\
\hline & City & 76 & 30.8 & 81 & 25.9 & 157 & 28 \\
\hline & Metropolis & 40 & 16.2 & 87 & 27.8 & 127 & 22.7 \\
\hline \multirow{3}{*}{ Faculty } & $\begin{array}{l}\text { Arts and } \\
\text { Science }\end{array}$ & 143 & 57.9 & 207 & 66.1 & 350 & 62.5 \\
\hline & FEAS & 47 & 19 & 46 & 14.7 & 93 & 16.6 \\
\hline & SPEA & 57 & 23.1 & 60 & 19.2 & 117 & 20.9 \\
\hline \multirow{4}{*}{$\begin{array}{l}\text { Mother's education } \\
\text { level }\end{array}$} & $\begin{array}{l}\text { Illiterate and } \\
\text { Literate }\end{array}$ & 91 & 36.8 & 60 & 19.2 & 151 & 27 \\
\hline & $\begin{array}{l}\text { Elementary } \\
\text { school }\end{array}$ & 106 & 42.9 & 159 & 50.8 & 265 & 47.3 \\
\hline & Middle school & 13 & 5.3 & 48 & 15.3 & 61 & 10.9 \\
\hline & $\begin{array}{l}\text { High school } \\
\text { and University }\end{array}$ & 37 & 15 & 46 & 14.7 & 83 & 14.8 \\
\hline \multirow{5}{*}{$\begin{array}{l}\text { Father's education } \\
\text { level }\end{array}$} & $\begin{array}{l}\text { Illiterate and } \\
\text { Literate }\end{array}$ & 40 & 16.2 & 14 & 4.5 & 54 & 9.6 \\
\hline & $\begin{array}{l}\text { Elementary } \\
\text { school }\end{array}$ & 78 & 31.6 & 126 & 40.3 & 204 & 36.4 \\
\hline & Middle school & 45 & 18.2 & 72 & 23 & 117 & 20.9 \\
\hline & High school & 60 & 24.3 & 66 & 21 & 126 & 22.5 \\
\hline & University & 24 & 9.7 & 35 & 11.2 & 59 & 10.5 \\
\hline
\end{tabular}


As shown in Table 1, 560 participants, 247 from KU and 313 from NOHU, participated in the study. When participants' ages are examined, it is seen that the most participants from both universities are from the 22-23 age range, the least from 26 and over. The number of participants from KU within 24-25 and 26 and over range are higher compared to same age range from NOHU. The number of participants within 20-21 and 22-23 are even lower. When an age-related evaluation is made, it can be said that the ages of KU participants are higher than NOHU participants' ages. The majority of participants from both universities are females, and they are still students. However, the number of female participants from NOHU is higher than KU participants. When their settlements are taken into consideration, it is seen that the most participants from both universities come from districts. However, $\mathrm{KU}$ participants come the least from metropolises, NOHU from villages-towns. In KU, participants from village-town, district and city are higher than NOHU, and participants from metropolises are lower. When participants' faculties from both universities are examined, the number of participants from arts and sciences are higher than FEAS and SPEA. When both universities are compared, the number of KU participants from the arts and science faculty is lower than NOHU participants, and number of participants from FEAS and SPEA are higher. When participants' mothers' education levels are compared, it is seen that the most participants' mothers are elementary school graduates. Number of KU illiterate-literate mothers is higher. The number of mothers graduating from middle school is higher in NOHU. When participants' fathers' education levels are examined, the number of fathers who were illiterate-literate and high school graduates are higher in KU while the number of fathers who graduated from elementary school, middle schools and university are higher in NOHU. When an evaluation related to mother and father education levels are made, it can be said that KU participants' education levels of parents are lower than NOHU participants'.

3.2 One-way Analysis of Variance Results of Participants' Perceived Teacher Self-efficacy according to the Age Variable

Table 2 shows the one-way ANOVA results of participants' scores from the Teachers' Sense of Efficacy Scale according to participants' age levels.

Table 2. One-way ANOVA results of participants' scores from the Teachers' Sense of Efficacy Scale according to participants' ages

\begin{tabular}{llllllll}
\hline Subscales & Source of & SS & df & MS & F & p & $\begin{array}{l}\text { Significant Difference } \\
\text { LSD }\end{array}$ \\
& Variance & & & & & & \\
Student & Between Group & 414.78 & 3 & 138.26 & 1.571 & .195 & \\
Engagement & Within Group & 48946.31 & 556 & 88.03 & & & \\
& Total & 49361.09 & 559 & & & & \\
\hline \multirow{2}{*}{ Instructional } & Between Group & 658.71 & 3 & 219.57 & 2.260 & .080 & \\
Practices & Within Group & 54012.82 & 556 & 97.14 & & & \\
& Total & 54671.53 & 559 & & & & \\
\hline \multirow{2}{*}{ Classroom } & Between Group & 1050.57 & 3 & 350.19 & 3.148 & $.025^{*}$ & $1-3$ \\
Management & Within Group & 61853.56 & 556 & 111.24 & & & \\
& Total & 62904.14 & 559 & & & & \\
\hline \multirow{2}{*}{ Total } & Between Group & 5356.72 & 3 & 1785.57 & 2.455 & .062 & \\
& Within Group & 404370.09 & 556 & 727.28 & & & \\
& Total & 409726.81 & 559 & & & & \\
\hline
\end{tabular}

$* \mathrm{p}<.05$

Table 2 shows that participants' views do not differ for Student Engagement $[(\mathrm{F}(3 ; 559)=1.57 ; \mathrm{p}>.05]$, Instructional Practices $[(\mathrm{F}(3 ; 559)=2.26 ; \mathrm{p}>.05]$ subscales and total scale $[(\mathrm{F}(3 ; 559)=2.45 ; \mathrm{p}>.05]$ according to age. Their views differ for Classroom Management subscale $[(\mathrm{F}(3 ; 559)=3.14 ; \mathrm{p}<.05]$ according to age. According to LSD test results in the Classroom Management subscale, there is a significant difference between 21-22 and 24-25 age groups. When arithmetic mean of these age groups' views is taken into account, it can be said that 24-25 age group ( $\bar{x}=57.33)$ 
consider themselves more competent compared to 21-22 age group $(\bar{x}=52.84)$. When arithmetic means of all subscales and total scale are taken into account 24-25 age group see themselves more competent about teaching than other age groups. In all subscales and total scale, 21-22 age group regarded themselves the least competent about teaching.

\subsection{T-test Results Of Participants' Perceived Teacher Self-efficacy according to the Sex Variable}

Table 3 shows the independent t-test results of participants' perceived self-efficacy according to the sex variable.

Table 3. Independent t-test results of participants' scores from the Teachers' Sense of Efficacy Scale according to the sex variable

\begin{tabular}{llllllll}
\hline Subscales & Sex & $\mathrm{N}$ & $\overline{\mathrm{x}}$ & $\mathrm{sd}$ & $\mathrm{df}$ & $\mathrm{t}$ & $\mathrm{p}$ \\
\hline \multirow{2}{*}{ Student Engagement } & Female & 355 & 52.80 & 9.21 & 558 & 1.792 & .074 \\
& Male & 205 & 54.28 & 9.66 & & & \\
\hline \multirow{2}{*}{ Instructional Practices } & Female & 355 & 52.61 & 9.88 & 558 & 2.529 & $.012^{*}$ \\
& Male & 205 & 54.79 & 9.77 & & & \\
\hline \multirow{2}{*}{ Classroom Management } & Female & 355 & 53.70 & 10.65 & 558 & 4.381 & $.001^{*}$ \\
& Male & 205 & 57.72 & 10.04 & & & \\
\hline \multirow{2}{*}{ Total } & Female & 355 & 159.12 & 27.16 & 558 & 3.257 & $.001^{*}$ \\
& Male & 205 & 166.80 & 26.28 & & & \\
\hline p<.05 & & & & & & &
\end{tabular}

As seen in Table 3, participants' views significantly differ for Instructional Practices [(t(558) $=2.52 ; \mathrm{p}<.05]$, Classroom Management [ $(\mathrm{t}(558)=4.38 ; \mathrm{p}<.05]$ and total scale [ $(\mathrm{t}(558)=3.25 ; \mathrm{p}<.05]$ according to sex. Yet, there is no significant difference for Student Engagement subscale according to sex. In Instructional Practices subscale, the arithmetic mean of male participants $(\bar{x}=54.79)$ is higher than females $(\bar{x}=52.61)$. In Classroom Management subscale, the arithmetic mean of male participants $(\bar{x}=57.7)$ is higher than females $(\bar{x}=53.70)$. For total scale, the arithmetic mean of male participants $(\bar{x}=166.80)$ is higher compared to females $(\bar{x}=159.12)$. In other words, compared to female participants, males consider themselves more competent about teaching.

3.4 T-test Results of Participants' Perceived Teacher Self-efficacy according to the Education Level Variable (Graduate-student)

Table 4 shows the independent t-test results of participants' perceived self-efficacy according to the education level variable.

Table 4. Independent t-test results of participants' scores from the Teachers' Sense of Efficacy Scale according to the education level variable

\begin{tabular}{llllllll}
\hline Subscales & Education & $\mathrm{N}$ & $\overline{\mathrm{x}}$ & $\mathrm{sd}$ & $\mathrm{df}$ & $\mathrm{t}$ & $\mathrm{p}$ \\
\hline Student & Graduate & 96 & 53.41 & 7.33 & 558 & .078 & .938 \\
Engagement & Student & 464 & 53.33 & 9.77 & & & \\
\hline Instructional & Graduate & 96 & 53.85 & 8.04 & 558 & .482 & .630 \\
Practices & Student & 464 & 53.31 & 10.23 & & & \\
\hline \multirow{2}{*}{ Classroom } & Graduate & 96 & 54.84 & 9.75 & 558 & .339 & .734 \\
Management & Student & 464 & 55.24 & 10.78 & & & .070 \\
\hline \multirow{2}{*}{ Total } & Graduate & 96 & 162.11 & 22.74 & 558 & & .944 \\
& Student & 464 & 161.90 & 27.90 & & & \\
\hline
\end{tabular}

$* \mathrm{p}<.05$ 
Table 4 shows that there is no significant difference between the views of participants who have graduated and are still students. However, when the arithmetic means of total scale are taken into account, arithmetic mean of graduate participants' views ( $\bar{x}=162.11)$ are higher than student participants' $(\bar{x}=161.90)$.

3.5 T-test Results of Participants' Perceived Teacher Self-efficacy according to the Universities Where Participants Take Their Pedagogical Formation Training

Table 5 shows the independent t-test results of participants' perceived self-efficacy based on the universities where candidates were enrolled.

Table 5. Independent t-test results of participants' scores from the Teachers' Sense of Efficacy Scale based on the universities where candidates were enrolled.

\begin{tabular}{llllllll}
\hline Subscales & University & $\mathrm{N}$ & $\overline{\mathrm{x}}$ & $\mathrm{sd}$ & $\mathrm{df}$ & $\mathrm{t}$ & $\mathrm{p}$ \\
\hline Student & $\mathrm{KU}$ & 247 & 54.58 & 10.13 & 558 & 2.779 & $.006^{*}$ \\
Engagement & NOHU & 313 & 52.37 & 8.66 & & & \\
\hline \multirow{2}{*}{ Instructional } & $\mathrm{KU}$ & 247 & 54.81 & 10.29 & 558 & 3.004 & $.003^{*}$ \\
Practices & NOHU & 313 & 52.30 & 9.42 & & & \\
\hline \multirow{2}{*}{ Classroom } & KU & 247 & 57.32 & 10.46 & 558 & 4.326 & $.001^{*}$ \\
Management & NOHU & 313 & 53.48 & 10.42 & & & \\
\hline \multirow{2}{*}{ Total } & KU & 247 & 166.72 & 28.07 & 558 & 3.761 & $.001^{*}$ \\
& NOHU & 313 & 158.15 & 25.67 & & & \\
\hline
\end{tabular}

*p<.05

As seen in Table 5, KU and NOHU participants' views significantly differ for Student Engagement $[(\mathrm{t}(558)=2.77 ; \mathrm{p}<.05]$, Instructional Practices [ $(\mathrm{t}(558)=3.00 ; \mathrm{p}<.05]$ and Classroom Management $[(\mathrm{t}(558)=4.32 ; \mathrm{p}<.05]$ subscales, and total scale $[(\mathrm{t}(558)=3.76 ; \mathrm{p}<.05]$. In Student Engagement subscale, KU participants' views $(\overline{\mathrm{x}}=54.58)$ are more positive than NOHU participants $(\bar{x}=52.37)$. In other words, in Student Engagement subscale, KU participants KU participants see themselves more competent about teaching than NOHU participants. In Instructional Practices subscale, KU participants' views $(\bar{x}=54.81)$ are more positive than NOHU participants $(\bar{x}=52.30)$. In other words, in Instructional Practices subscale, participants in KU participants see themselves more competent about teaching than NOHU participants. In Classroom Management, KU participants' views are more positive than NOHU participants $(\bar{x}=53.48)$. In other words, in Classroom Management subscale, KU participants consider themselves more competent about teaching than NOHU participants. In total scale, KU participants' views $(\bar{x}=166.72)$ are more positive than NOHU participants $(\bar{x}=158.15)$. In other words, KU participants regard themselves more competent about teaching than NOHU participants. 
3.6 One-way ANOVA Results of Participants' Perceived Teacher Self-efficacy Levels Based on the Administrative Unit They have Lived the Longest

Table 6 shows the one-way ANOVA results of participants' perceived self-efficacy based on the administrative unit they have lived the longest.

Table 6. One-way ANOVA results of participants' scores from the Teachers' Sense of Efficacy Scale based on the administrative unit they have lived the longest

\begin{tabular}{llllllll}
\hline \multirow{2}{*}{ Subscale } & Source of & SS & df & MS & F & p & $\begin{array}{l}\text { Significant Difference } \\
\text { LSD }\end{array}$ \\
& Variance & & & & & & \\
Student & Between Group & 725.99 & 3 & 241.99 & 2.767 & $.041^{*}$ & $1-4$ \\
Engagement & Within Group & 48635.10 & 556 & 87.47 & & & $2-4$ \\
& Total & 49361.09 & 559 & & & $3-4$ \\
\hline \multirow{2}{*}{ Instructional } & Between Group & 831.86 & 3 & 277.28 & 2.864 & $.036^{*}$ & $2-4$ \\
Practices & Within Group & 53839.67 & 556 & 96.83 & & $3-4$ \\
& Total & 54671.53 & 559 & & & & \\
\hline \multirow{2}{*}{ Classroom } & Between Group & 645.78 & 3 & 215.26 & 1.922 & .125 & - \\
Management & Within Group & 62258.35 & 556 & 111.97 & & & \\
& Total & 62904.14 & 559 & & & & \\
\hline \multirow{2}{*}{ Total } & Between Group & 6235.99 & 3 & 2078.66 & 2.864 & $.036^{*}$ & $2-4$ \\
& Within Group & 403490.81 & 556 & 725.70 & & & $3-4$
\end{tabular}

$* \overline{\mathrm{p}<.05}$

Table 6 shows that there are significant differences between participants' views in Student Engagement and Instructional Practices subscales and total scale according to the settlement unit they have lived the most. In Student Engagement subscale, there are significant differences between the participants who have lived in metropolises the longest and the ones in villages-towns, districts and cities $[(\mathrm{F}(3 ; 559)=2.76 ; \mathrm{p}>.05]$. According to LSD test results, arithmetic mean of views of participants who have lived in metropolises $(\bar{x}=55.37)$ the longest is higher than the ones who have lived in villages-towns $(\bar{x}=52.56)$, districts $(\bar{x}=53.17)$ and cities $(\bar{x}=52.43)$. Therefore, it can be assumed that living in metropolises gave an advantage to participants about self-efficacy in Student Engagement subscale. In Instructional Practices subscale, there are significant differences between the participants who have lived in metropolises the longest and the ones in districts and cities $[(\mathrm{F}(3 ; 559)=2.86 ; \mathrm{p}>.05]$. According to LSD test results, arithmetic mean of views of participants who have lived in metropolises $(\bar{x}=55.56)$ the longest is higher than the ones who have lived in districts $(\bar{x}=52.83)$ and cities $(\bar{x}=52.32)$. An explanation for this is that living in metropolises gave an advantage to the participants about self-efficacy in Instructional Practices subscale compared to the ones who have lived in districts and cities.

In total scale, there are significant differences between the participants who have lived in metropolises the longest and the ones in districts and cities $[(\mathrm{F}(3 ; 559)=2.86 ; \mathrm{p}>.05]$. According to LSD test results, arithmetic mean of views of participants who have lived in metropolises $(\bar{x}=167.93)$ the longest is higher than the ones who have lived in districts $(\bar{x}=160.28)$ and cities $(\bar{x}=159.23)$. From this finding, it can be understood that living in metropolises gave an advantage to the participants about teacher self-efficacy compared to the ones who have lived in districts and cities. 
3.7 One-way ANOVA Results of Participants' Perceived Teacher Self-efficacy Levels according to the Faculty Variable

Table 7 shows one-way ANOVA results of participants' Teachers' Sense of Efficacy Scale scores according to faculties.

Table 7. One-way ANOVA results of participants' Teachers' Sense of Efficacy Scale scores according to faculties

\begin{tabular}{|c|c|c|c|c|c|c|c|}
\hline Subscales & $\begin{array}{l}\text { Source of } \\
\text { Variance }\end{array}$ & SS & $\mathrm{df}$ & MS & $\mathrm{F}$ & $\mathrm{p}$ & $\begin{array}{l}\text { Significant Difference } \\
\text { LSD }\end{array}$ \\
\hline \multirow{3}{*}{$\begin{array}{l}\text { Student } \\
\text { Engagement }\end{array}$} & Between Group & 715.79 & 2 & 357.89 & 4.098 & $.017^{*}$ & $2-1$ \\
\hline & Within Group & 48645.29 & 557 & 87.33 & & & $2-3$ \\
\hline & Total & 49361.09 & 559 & & & & \\
\hline \multirow{3}{*}{$\begin{array}{l}\text { Instructional } \\
\text { Practices }\end{array}$} & Between Group & 1198.55 & 2 & 599.27 & 6.242 & $.002 *$ & $3-1$ \\
\hline & Within Group & 53472.98 & 557 & 96.00 & & & $3-2$ \\
\hline & Total & 54671.53 & 559 & & & & \\
\hline \multirow{3}{*}{$\begin{array}{l}\text { Classroom } \\
\text { Management }\end{array}$} & Between Group & 677.66 & 2 & 338.83 & 3.033 & $.049 *$ & $2-1$ \\
\hline & Within Group & 62226.49 & 557 & 111.71 & & & $2-3$ \\
\hline & Total & 62904.14 & 559 & & & & \\
\hline \multirow{3}{*}{ Total } & Between Group & 6235.99 & 2 & 3679.69 & 5.094 & $.006^{*}$ & $2-1$ \\
\hline & Within Group & 403490.81 & 557 & 772.38 & & & $2-3$ \\
\hline & Total & 409726.81 & 559 & & & & \\
\hline
\end{tabular}

$* \overline{\mathrm{p}}<.05$

Table 7 shows that there are significant differences in participants' views in Student Engagement, Instructional Practices and Classroom Management subscales and total scale according to participants' faculties. In Student Engagement subscale, there are significant differences between the participants from FAES and the ones from arts and science and SPEA $[(\mathrm{F}(2 ; 559)=4.09 ; \mathrm{p}>.05]$. According to LSD test results, in Student Engagement subscale, arithmetic mean of views of participants from FAES $(\bar{x}=51.22)$ is lower than the ones from arts and science $(\bar{x}$ $=53.38)$ and SPEA $(\bar{x}=54.94)$. This finding can be interpreted as participants from FAES consider themselves less competent than participants from other faculties in Student Engagement subscale. In Instructional Practices subscale, there are significant differences between the participants from SPEA and the ones from arts and science and FEAS $[(\mathrm{F}(2 ; 559)=6.24 ; \mathrm{p}>.05]$. According to LSD test results, in the Student Engagement subscale, arithmetic mean of views of participants from SPEA $(\bar{x}=55.85)$ is higher than the ones from arts and science $(\bar{x}=53.20)$ and FEAS $(\bar{x}$ $=51.12$ ). This can be explained participants from SPEA considering themselves more competent than participants from other faculties in Student Engagement subscale. In Classroom Management subscale, there are significant differences between the participants from FEAS and the ones from arts and science and SPEA $[(\mathrm{F}(2 ; 559)=3.03 ; \mathrm{p}>.05]$. According to LSD test results, in Classroom Management subscale, arithmetic mean of views of participants from FEAS $(\bar{x}=52.84)$ is lower than the ones from arts and science $(\bar{x}=55.41)$ and SPEA $(\bar{x}$ $=56.32$ ). As a result of this finding, it can be assumed that participants from FEAS consider themselves less competent than participants from other faculties in Classroom Management subscale.

In total scale, there are significant differences between the participants from FAES, arts and science, and SPEA $[(\mathrm{F}(2 ; 559)=5.09 ; \mathrm{p}>.05] . \quad$ According to LSD test results, arithmetic mean of views of FEAS participants $(\overline{\mathrm{x}}=155.20)$ is lower than arts and science participants $(\bar{x}=161.99)$ and SPEAS participants $(\bar{x}=167.11)$. This can be explained by participants from FAES considering themselves less competent than other participants. 
3.8 One-way ANOVA Results of Participants' Perceived Teacher Self-efficacy Levels according to the Mother's Education Level Variable

Table 8 shows one-way ANOVA results of participants' Teachers' Sense of Efficacy Scale scores according to mothers' education levels.

Table 8. One-way ANOVA results of participants' Teachers' Sense of Efficacy Scale scores according to mothers' education levels.

\begin{tabular}{|c|c|c|c|c|c|c|c|}
\hline Subscale & $\begin{array}{l}\text { Source of } \\
\text { Variance }\end{array}$ & SS & df & MS & $\mathrm{F}$ & $\mathrm{p}$ & $\begin{array}{l}\text { Significant Difference } \\
\text { LSD }\end{array}$ \\
\hline \multirow{3}{*}{$\begin{array}{l}\text { Student } \\
\text { Engagement }\end{array}$} & Between Group & 776.36 & 3 & 258.78 & 2.962 & $.032 *$ & $2-1$ \\
\hline & Within Group & 48584.73 & 556 & 87.38 & & & $2-3$ \\
\hline & Total & 49361.09 & 559 & & & & \\
\hline \multirow{3}{*}{$\begin{array}{l}\text { Instructional } \\
\text { Practices }\end{array}$} & Between Group & 362.07 & 3 & 120.69 & 1.236 & .296 & \\
\hline & Within Group & 54309.46 & 556 & 97.67 & & & \\
\hline & Total & 54671.53 & 559 & & & & \\
\hline \multirow{3}{*}{$\begin{array}{l}\text { Classroom } \\
\text { Management }\end{array}$} & Between Group & 570.96 & 3 & 190.32 & 1.698 & .166 & \\
\hline & Within Group & 62333.18 & 556 & 112.11 & & & \\
\hline & Total & 62904.14 & 559 & & & & \\
\hline \multirow{3}{*}{ Total } & Between Group & 4099.88 & 3 & 1366.62 & 1.873 & .133 & \\
\hline & Within Group & 405626.93 & 556 & 729.54 & & & \\
\hline & Total & 409726.81 & 559 & & & & \\
\hline
\end{tabular}

\section{$* \mathrm{p}<.05$}

Table 8 shows that there are significant differences between participants' views in Student Engagement subscale according to participants' mothers' education levels. In Student Engagement subscale, there are significant differences between the participants' mothers who are illiterate-literate and who are middle school graduates $[(\mathrm{F}(3 ; 559)=2.96 ; \mathrm{p}>.05]$. According to LSD test results, in Student Engagement subscale, arithmetic mean of views of participants' mothers who are elementary school graduates $(\bar{X}=52.18)$ is lower than the ones who are illiterate-literate $(\bar{X}=54.45)$ and middle school graduates $(\bar{X}=55.27)$. This finding can be explained as participants whose mothers are elementary school graduates consider themselves as less competent than participants whose mothers are illiterate-literate and middle school graduates. In other subscales and total scale, there are not significant differences in perceived teacher self-efficacy according to participants' mothers' education levels. 
3.9 One-way ANOVA Results of Participants' Perceived Teacher Self-efficacy Levels according to the Father's Education Level Variable

Table 9 shows one-way ANOVA results of participants' Teachers' Sense of Efficacy Scale scores according to fathers' education levels.

Table 9. One-way ANOVA results of participants' Teachers' Sense of Efficacy Scale scores according to fathers' education levels.

\begin{tabular}{|c|c|c|c|c|c|c|c|}
\hline Subscale & $\begin{array}{l}\text { Source of } \\
\text { Variance }\end{array}$ & SS & $\mathrm{df}$ & MS & $\mathrm{F}$ & $\mathrm{p}$ & $\begin{array}{l}\text { Significant Difference } \\
\text { LSD }\end{array}$ \\
\hline \multirow{3}{*}{$\begin{array}{l}\text { Student } \\
\text { Engagement }\end{array}$} & Between Group & 59.88 & 4 & 14.97 & .169 & .954 & \\
\hline & Within Group & 49301.21 & 555 & 88.83 & & & \\
\hline & Total & 49361.09 & 559 & & & & \\
\hline \multirow{3}{*}{$\begin{array}{l}\text { Instructional } \\
\text { Practices }\end{array}$} & Between Group & 142.13 & 4 & 35.53 & .362 & .836 & \\
\hline & Within Group & 54529.40 & 555 & 98.25 & & & \\
\hline & Total & 54671.53 & 559 & & & & \\
\hline \multirow{3}{*}{$\begin{array}{l}\text { Classroom } \\
\text { Management }\end{array}$} & Between Group & 421.84 & 4 & 105.46 & .937 & .442 & \\
\hline & Within Group & 62482.30 & 555 & 112.58 & & & \\
\hline & Total & 62904.14 & 559 & & & & \\
\hline \multirow{3}{*}{ Total } & Between Group & 1059.21 & 4 & 264.80 & .360 & .837 & \\
\hline & Within Group & 408667.59 & 555 & 736.33 & & & \\
\hline & Total & 409726.81 & 559 & & & & \\
\hline
\end{tabular}

$* \mathrm{p}<.05$

In all subscales and total scale, there are not significant differences in perceived teacher self-efficacy according to participants' fathers' education levels.

\section{Discussion}

In this study, perceived teacher self-efficacy of candidates enrolled in two different universities' pedagogical formation programs was examined according to various variables. Teacher self-efficacy has thus been tried to be understood through the factors that may be related. In this context, whether or not teacher self-efficacy differed according to candidates' ages, sexes, education levels, settlements they have lived the longest, faculties, universities where they are enrolled for teacher training program, and mother's and father's education levels. As a result of this study, the following results were reached:

In all subscales and total scale, it was found that candidates in the 24-25 age group considered themselves more competent compared to other age groups. In all subscales and total scale, the age group that considered themselves the least competent was the 21-22 group. While some studies on self-efficacy (Aypay, 2010; Scholz, Gutierrez-Dona, Sud \& Schwarzer, 2002) found significant differences according to age, some studies did not (Yildırım \& Ilhan, 2010; Brink, Alsen, Herlitz, Kjellgren \& Cliffordson, 2012). In the studies where significant difference was found, similar to this study, the youngest age group exhibited the lowest self-efficacy.

Candidates' views significantly differed for Instructional Practices and Classroom Management subscales and total scale according to sex. There was no significant difference for Student Engagement subscale. A similar result can be found in Demirtaş et al.'s (2011) and Ünlü et al.'s (2017) studies. According to their results, in Instructional Practices and Classroom management subscales, male teachers' and female teachers' views differed, too. Similar to this study, male candidates regarded themselves more competent than females. A similar result was found in Karadağ et al.'s study. In their study, too, male candidates saw themselves more competent in Classroom Management, Instructional Practices and Student Engagement subscales. Also, in studies conducted by Yeşilyurt (2013), Özdemir (2008), Çapri and Çelikkaleli (2008) and Morgül et al. (2004) male teacher candidates' self-efficacy beliefs were found higher. This can be attributed to males in Turkey trusting themselves more in many areas due to 
social norms and values. These social norms and values deeply reflect male dominated approaches. To overcome these norms and values causing women to be subordinates of men in society, practices that are socially equal should be include in all spheres of social life. At the same time, it would be meaningful to fight with all sexist approaches negatively affecting female students' self-efficacy in education faculties and to offer courses about gender equality in teacher training programs. Studies conducted by Kutluca and Aydın (2016), Baykara (2011), Şahin-Taşkın and Haciömeroğlu (2010), and Saracaoğlu and Yenice (2009) determined that teacher self-efficacy did not differ significantly according to sex.

It is seen that there was no significant difference between participants who have graduated and are still students. However, it can be said that graduate students had higher self-efficacy beliefs. Similarly, Bümen and Özaydın (2013) determined that graduates had more self-efficacy. This can be attributed to students thinking about finishing school first and graduates already working in teaching-related jobs.

KU and NOHU teacher candidates' views on teacher self-efficacy significantly differed in Student Engagement, Instructional Practices and Classroom Management subscales and total scale. KU teacher candidates' views on teacher self-efficacy were more positive. In other words, KU candidates considered themselves more competent than NOHU candidates. This finding suggests that there may be a relationship between teacher self-efficacy, institution where the teacher training take place, institution culture and informal processes going on in training programs. However, contrary to this study's result, in Özdemir's (2008) study, there was no significant difference between candidates according to the universities they were enrolled in. Therefore, it would be meaningful to conduct qualitative studies closely examining the relationship between teacher training processes and teacher self-efficacy.

Candidates' views significantly differed for Student Engagement and Instructional Practice subscales and total scale according to the settlement they have lived the longest. There were significant differences between candidates who have lived in metropolises and in villages-towns, districts and cities. It can be said that living in metropolises gave them an advantage. Similarly, Korkut and Babaoğlan (2012) determined that self-efficacy of teachers working in cities were higher than the ones in districts and villages. Bandura's (1999) reciprocal interaction principle argues that people are affected by their environment, and they affect their environment. Accordingly, it may be normal for people living or working in metropolises to have higher perceived self-efficacy because socioeconomic development of metropolises can enrich candidates' experiences and offer them better opportunities for teacher-related experiences. In this framework, it would be meaningful to reconsider the Turkish education policy of opening a university in every city and to reconsider the status of teacher training programs and faculties already opened in cities that do not reach a certain level of socio-economic development and that do not have the capacity for students' social development.

Candidates' views significantly differed for Student Engagement, Instructional Practice and Classroom Management subscales and total scale according to their faculties. Candidates from SPEA considered themselves more competent than the ones from arts and sciences and FEAS. Also, candidates from FEAS saw themselves less competent than the others. This finding shows similarity to the study conducted by Gürbüztürk and Şad (2006). They determined that SPEA candidates regarded themselves more competent. These results can be attributed to the fact that SPEA student are admitted to university after ability exams. Similarly, Çakır, Kan and Sünbül (2006) found that candidates from social sciences have higher elf-efficacy than candidates from science and math. Studies on students from different grade levels in Turkey (Nacakc1, 2006; Yetim, 2006) determined that student attitudes towards courses based on ability like physical education, painting and music are more positive. Therefore, it can be said that the desire to become teachers of these courses and thus to have higher self-efficacy about this can start before university. Also, according to Çapri and Çelikkaleli's (2008) study, teacher self-efficacy differs according to faculties. However, there are studies (Ilgaz, Bülbül \& Çuhadar, 2013; Elkatmış, Demirbaş \& Ertuğrul 2013) that found no faculty effect on teacher self-efficacy. Conducted with students enrolled in a university's pedagogical formation program, Dadandi et al.'s (2016) study determined no difference between these two groups.

There is a significant difference between candidates' teacher self-efficacy only in Student Engagement subscale according to mother' education level. Candidates whose mothers graduated from elementary school considered themselves less competent than candidates whose mothers were illiterate-literate and middle school graduates. According to Gözüm's (2015) study, self-efficacy of candidates whose mothers were illiterate were higher in some teaching fields (preschool teaching). However, in fields other than preschool teaching there were no significant differences according to mother's education level. According to candidates' fathers' education levels, there are not significant differences. In this respect, Gözüm's (2015) study is parallel with this study's finding. Contrary to this 
study, the studies of İnnalı and Aydın (2014) and Çetin (2008) show that as mothers' and fathers' education levels increase, perceived self-efficacy also increases.

\section{Acknowledgement}

We thank all the participants.

\section{References}

Aypay, A. (2010). The adaptation study of general self-efficacy scale to Turkish. Inonu University Journal of the Faculty of Education, 11(2), 113-131. http://dx.doi.org/10.17679/iuefd.33205

Ballesteros, F. R., \& Nicolás, J. D., \& Caprara, G.V., \& Barbaranelli, C., \& Bandura, A. (2002). Determinants and structural relation of personal efficacy to collective efficacy. Applied Psychology: An International Review, 51(1), 107-125. http://dx.doi.org/10.1111/1464-0597.00081

Bandura, A. (1984). Recycling misconceptions of perceived self-efficacy. Cognitive Therapy and Research, 8(3), 231-255. http://dx.doi.org/10.1007/BF01172995

Bandura, A. (1999). Social cognitive theory: An agentic perspective. Asian Journal of Social Psychology, 2, 21-41. http://dx.doi.org/10.1111/1467-839X.00024

Bandura, A. (2002). Social cognitive theory in cultural context. Applied Psychology: An International Review, 51(2), 269-290. http://dx.doi.org/10.1111/1464-0597.00092

Bandura, A. \& Adams, N.E. (1977). Analysis of self-efficacy theory of behavioral change. Cognitive Therapy and Research, 1(4), 287-310. https://doi.org/10.1007/BF01663995

Baykara, K. (2011). Öğretmen adaylarının bilişötesi öğrenme stratejileri ile öğretmen yeterlik algıları üzerine bir çalışma. Hacettepe Unv. Eğitim Fakültesi Dergisi, 40, 80-92.

Benight, C., \& Bandura, A. (2004). Social cognitive theory of posttraumatic recovery: The role of perceived self efficiacy. Behaviour Research and Therapy, 42, 1129-1148. http://dx.doi.org/10.1016/j.brat.2003.08.008

Brígido, M., \& Borrachero, A.B. \& Bermejo, M.L. \& Mellado, V. (2013). Prospective primary teachers' self-efficacy and emotions in science teaching. European Journal of Teacher Education, 36(2), 200-217. http://dx.doi.org/10.1080/02619768.2012.686993Brink, E., \& Alsén, P., \& Herlitz, J., \& Kjellgren K., \& Cliffordson C.(2012). General self-efficacy and health-related quality of life after myocardial infarction. Psychol Health Med, 17(3), 346-55. doi: 10.1080/13548506.2011.608807

Brown, A. L., \& Lee, J., \& Collins, D. (2015). Does student teaching matter? Investigating pre-service teachers' sense of efficacy and preparedness, Teaching Education, 26 (1), 77-93, http://dx.doi.org/10.1080/10476210.2014.957666

Bümen, N. T., \& Özaydın, T. (2013). Adaylıktan göreve öğretmen özyeterliği ve öğretmenlik mesleğine yönelik tutumlardaki değişimler. Eğitim ve Bilim, 38(169), 109-125.

Caprara, G. V., \& Barbaranelli, C., \& Steca, P., \& Malone, P. S. (2006). Teachers' self-efficacy beliefs as determinants of job satisfaction and students' academic achievement: A study at the school level. Journal of School Psychology, 44(6), 473-490. https://doi.org/10.1016/j.jsp.2006.09.001

Creswell, J. W. (2014). Research Design: Qualitative, Quantitative, and Mixed Methods Approaches. London: SAGE Publications Ltd.

Çakır, Ö., \& Kan, A., \& Sünbül, Ö. (2006). Öğretmenlik meslek bilgisi ve tezsiz yüksek lisans programlarının tutum ve özyeterlik açısından değerlendirilmesi. Mersin Üniversitesi Eğitim Fakültesi Dergisi, 2(1), 36-47.

Çapa, Y., \& Çakıroğlu, J., \& Sarıkaya, H. (2005). The development and validation of a Turkish version of teachers' sense of efficacy scale. Education and Science, 30(137), 74- 81.

Çapri, B., \& Çelikkaleli, Ö. (2008). Öğretmen adaylarının öğretmenliğe ilişkin tutum ve mesleki yeterlik inançlarının cinsiyet, program ve fakültelerine göre incelenmesi. İn̈̈ü Üniversitesi Eğitim Fakültesi Dergisi, 9(15), 33-53. http://dx.doi.org/10.17679/iuefd.18403

Çetin, B. (2008). Fen bilgisi öğretimi dersinin sınıf öğretmenliği anabilim dalı 3. Sınıf öğrencilerinin fen öğretimindeki öz-yeterlik inançlarına etkisi. Dokuz Eylül Üniversitesi Sosyal Bilimler Enstitüsü Dergisi, 10(2), $55-71$.

Dadandı, İ., \& Kalyon, A., \& Yazıcı, H. (2016). Eğitim fakültesinde öğrenim gören ve pedagojik formasyon eğitimi 
alan öğretmen adaylarının öz-yeterlik inançları, kaygı düzeyleri ve öğretmenlik mesleğine karşı tutumları. Bayburt Eğitim Fakültesi Dergisi, 11(1), 253-269.

Demirtaş, H., \& Cömert, M., \& Özer, N. (2011). Öğretmen adaylarının özyeterlik inançları ve öğretmenlik mesleğine ilişkin tutumları. Eğitim ve Bilim, 36(159), 96-111.

Elkatmış, M., \& Demirbaş, M., \& Ertuğrul, N. (2013). Eğitim fakültesi öğrencileri ile formasyon eğitimi alan fen edebiyat fakültesi öğrencilerinin öğretmenlik mesleğine yönelik öz yeterlik inançları. Pegem Eğitim ve Öğretim Dergisi, 3(3), 41-50. https://doi.org/10.14527/C3S3M4

Gecas, V. (1989). The social psychology of self-efficacy. Annual Review of Sociology, 15, 291-316. http://dx.doi.org/10.1146/annurev.so.15.080189.001451

Gist, M.E. (1987). Self-efficacy: Implications for organizational behavior and human resource management. The Academy of Management Review, 12(3), 472-485.http://dx.doi.org/10.5465/AMR.1987.4306562

Gist, M. E., \& Mitchell, T.R. (1992). Self-efficacy: A theoretical analysis of its determinants and malleability. The Academy of Management Review, 17(2), 183-211. http://dx.doi.org/10.5465/AMR.1992.4279530

Goddard, R. D., Hoy, W. K. \& Hoy, A. W. (2000). Collective teacher efficacy: Its meaning, measure, and impact on student achievement. American Educational Research Journal, 37(2), 479-507. https://doi.org/10.3102/00028312037002479

Gözüm, A., \& İ. C. (2015). Okul öncesi, sınıf ve fen bilgisi öğretmenlerinin fen bilimleri öz -yeterliklerine göre sosyo- bilimsel tutum ve bilişsel yapılarının belirlenmesi (Kars ili örneği). Yayınlanmamış doktora tezi, Samsun: Ondokuz Mayıs Üniversitesi, Eğitim Bilimleri Enstitüsü.

Guskey, T. R. (1988). Teacher efficacy, self-concept, and attitudes toward the implementation of instructional innovation. Teaching and Teacher Education, 4(1), 63-69. http://dx.doi.org/10.1016/0742-051X(88)90025-X

Gürbüztürk, O., \& Şad, S. N. (2009). Student teachers' beliefs about teaching and their sense of self-efficacy: A descriptive and comparative analysis. Iпӧnӥ Üniversitesi Eğitim Fakültesi Dergisi, 10(3), 201-226. http://dx.doi.org/10.17679/iuefd.55561

Ilgaz, G., \& Bülbül, T., \& Çuhadar, C. (2013). Öğretmen adaylarının eğitim inançları ile öz yeterlik algıları arasındaki ilişkinin incelenmesi. Abant İzzet Baysal Üniversitesi Eğitim Fakültesi Dergisi, 13(1), 50-65.

İnnalı, H. Ö., \& Aydın, İ. S. (2014). İlköğretim 8. sınıf öğrencilerinin okur öz yeterliklerinin çeşitli değişkenlere göre incelenmesi. Turkish Studies, 9(9), 651-682. http://dx.doi.org/10.17827/TurkishStudies.7132

Karadağ, E., \& Baloğlu, N., \& Çalışkan, N. (2009, May). Öğretmen adaylarının stresle başa çıkma yolları ve yetkinlik duygusu yönelimleri: Bir MANAVO analizi. Paper presented at the 1st International Congress of Educational Research. Çanakkale-Turkey.

Karasar, N. (2012). Bilimsel araştırma yöntemi. (23th. ed.). Ankara: Nobel Yayıncıllk.

Korkut, K., \& Babaoğlan, E. (2012). Sınıf öğretmenlerinin öz yeterlik inançları. Uluslararası Yönetim İktisat ve İsletme Dergisi, 8(16), 269-282. http://dx.doi.org/10.11122/ijmeb.2014.8.16.315

Kutluca, A. Y., \& Aydın, A. (2016). Fen bilgisi öğretmen adaylarının öz-yeterlik inançlarının çeșitli değişkenler açısından incelenmesi: Oluşturmacı öğretimin etkisi. Abant İzzet Baysal Üniversitesi Eğitim Fakültesi Dergisi, 16(1), 217-236. http://dx.doi.org/10.17240/aibuefd.2016.16.1-5000182919

MEB (2008). Öğretmen yeterlikleri: Öğretmenlik mesleği genel ve özel alan yeterlikleri. Ankara: Devlet Kitapları Müdürlüğü.

Menon, D., \& Sadler, T. D. (2016). Preservice elementary teachers' science self-efficacy beliefs and science content knowledge. Journal of Science Teacher Education, 27(6), 649-673. http://dx.doi.org/10.1007/s10972-016-9479-y

Morgül, İ., \& Seçken, N., \& Yücel, A. S. (2004). Kimya öğretmen adaylarının özyeterlik inançlarının bazı değişkenler açısından incelenmesi. Balıkesir Üniversitesi Fen Bilimleri Enstitüsü Dergisi, 6(1), 62-72.

Nacakc1, Z. (2006, 26-28 April). İlköğretim öğrencilerinin müzik dersine ilişkin tutumları. Ulusal Müzik Eğitimi Sempozyumunda Sunulan Bildiri. Pamukkale Üniversitesi-Denizli.

Özdemir, S. M. (2008). Sınıf öğretmeni adaylarının öğretim sürecine ilişkin özyeterlik inançlarının çeşitli değişkenler açısından incelenmesi. Kuram ve Uygulamada Eğitim Yönetimi, 14(2), 277-306. 
Petchauer, E. (2016). Shall we overcome? Self-efficacy, teacher licensure exams, and African American preservice teachers. The New Educator, 12(2), 171-190. http://dx.doi.org/10.1080/1547688X.2016.1156456

Saracaloğlu, A. S., \& Yenice, N. (2009). Fen bilgisi ve sınıf öğretmenlerinin öz yeterlik inançlarının bazı değişkenler açısından incelenmesi. Eğitimde Kuram ve Uygulama,5(2), 244-260. http://dx.doi.org/10.17244/eku.28695

Scholz, U., \& Gutierrez-Dona, B., Sud, S., and Schwarzer, R. (2002). Is general self-efficacy a universal construct? European Journal of Psychological Assessment, 18(3), 242-251. https://doi.org/10.1027//1015-5759.18.3.242

Schunk, D. H. (2009). Öğrenme teorileri: Eğitimsel bir baklşla [Learning theories:An educational perspective](5th ed.) Ankara: Nobel Yayın Dağıtım.

Stein, M. K., \& Wang, M. C. (1988). Teacher development and school improvement: The process of teacher change. Teaching and Teacher Education, 4, 171-187. http://dx.doi.org/10.1016/0742-051X(88)90016-9

Şahin-Taşkın, Ç., \& Hacıömeroğlu, G. (2010). Sınıf öğretmeni adaylarının özyeterlik inançları: Nicel ve nitel verilere dayalı bir inceleme. İnönü Üniversitesi Ĕgitim Fakültesi Dergisi. 11(1), 21-40. http://dx.doi.org/10.17679/iuefd.97972

TED. (2009). Öğretmen yeterlikleri. Ankara: 2009.

Tschannen-Moran, M. \& Hoy, A. W. (2001). Teacher efficacy: Capturing an elusive construct. Teaching and Teacher Education, 17 (7), 783-805. http://dx.doi.org/10.1016/S0742-051X(01)00036-1

Tuchman, E., \& Isaacs, J. (2011). The influence of formal and informal formative pre-service experiences on teacher self-efficacy. Educational Psychology, 31(4), 413-433. http://dx.doi.org/10.1080/01443410.2011.560656

Ünlü, İ., \& Kaşkaya, A., \& Kızılkaya M. F. (2017). Sosyal bilgiler öğretmen adaylarının öz-yeterlik inançlarının çeşitli değişkenler açısından incelenmesi. Ahi Evran Üniversitesi Kırşehir Eğitim Fakültesi Dergisi (KEFAD), 18(2), 651-668. Yeşilyurt, E. (2013). Öğretmen adaylarının öğretmen öz-yeterlik algıları. Elektronik Sosyal Bilimler Dergisi, 12(45), 88-104. ISSN:1304-0278

Yetim, H. (2006). İlköğretim 8. Sinıf Öğrencilerinin Matematik ve Türkçe Derslerine Yönelik Tutumları ile Bu Derslerdeki Başarısı Arasındaki İlişki, yayımlanmamış doktora tezi, İzmir: Dokuz Eylül Üniversitesi, Eğitim Bilimleri Enstitüsü.

Yeung, K.W., \& Watkins, D. (2000). Hong Kong student teachers' personal construction of teaching efficacy. Educational Psychology, 20(2), 213-235. http://dx.doi.org/10.1080/713663713

Yıldırım, F., \& İlhan, İ.Ö. (2010). Genel özyeterlilik ölçeği türkçe formunun geçerlilik ve güvenilirlik çalışması. Türk Psikiyatri Dergisi, 21(4), 301-308.

Woolfolk, A. E. \& Hoy, W. K. (1990). Prospective teachers' sense of efficacy and beliefs about control. Journal of Educational Psychology, 82(1), 81-91. http://dx.doi.org/10.1037/0022-0663.82.1.81 


\section{Appendix}

"Teachers' Sense of Efficacy Scale"

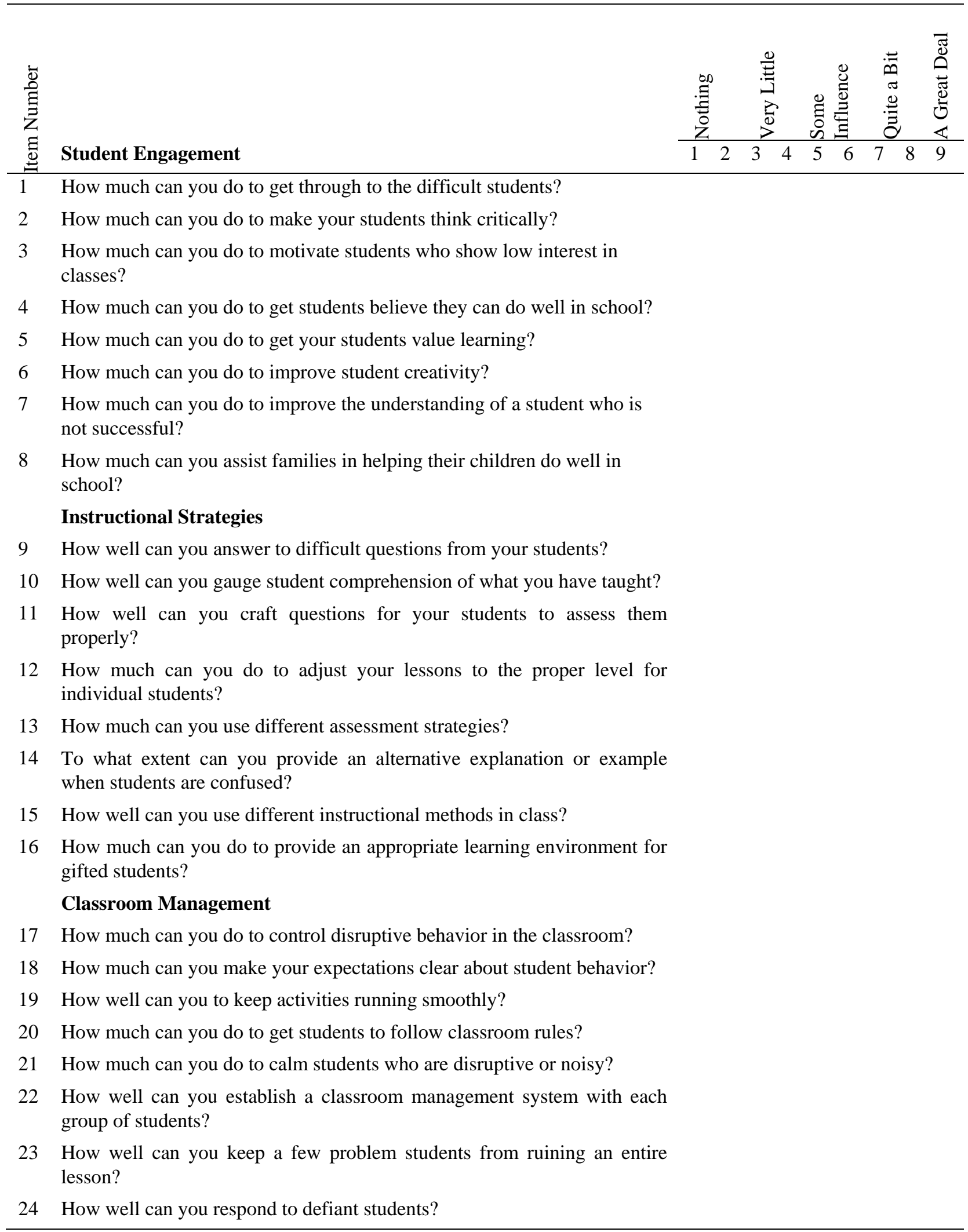

